\title{
Pemberdayaan Berbasis Asset Based Community Development (ABCD) untuk Meningkatkan Kompetensi Profesional Guru Madrasah di Era Industri 4.0
}

\author{
Alhamuddin 1*, Helmi Aziz 2, Dinar Nur Inten ${ }^{3}$, Dewi Mulyani 4 iD \\ 1,2,3,4 Universitas Islam Bandung, Indonesia \\ *Corresponding author: alhamuddinpalembang@gmail.com
}

\begin{abstract}
Meningkatkan kompetensi profesional guru Madrasah di era industri 4.0 sangat penting, sehingga diperlukan adanya suatu Pemberdayaan. Pemberdayaan ini bertujuan untuk meningkatkan kompetensi professional guru madrasah di kecamatan Cimaung Provinsi Jawa Barat. Pendekatan dalam melaksanakan pemberdayaan menggunakan Asset Based Community Development (ABCD). Pendekatan ini digunakan untuk mengoptimalkan potensi dan aset yang dimiliki masyarakat dampingan. Focus pemberdayaan ini adalah pelatihan dan pendampingan terkait dengan peningkatan kompetensi profesional guru-guru madrasah yang ada di kecamatan Cimaung. Hasil pemberdayaan menunjukkan bahwa kompetensi professional guru madrasah mengalami peningkatan secara signifikan melalui beberapa kegiatan yang sudah dilakukan; literasi untuk anak usia dini, internalisasi nilai-nilai pendidikan Islam dalam kurikulum dan pembelajaran, serta kompetensi professional guru di era industry 4.0. Pemberdayaan untuk guru-guru madrasah perlu senantiasa dilaksanakan secara berkesinambungan (continuous quality improvement) sehingga dapat meningkatkan kompetensi guru-guru dengan baik.
\end{abstract}

Keywords: Guru, Madrasah, ABCD, Industri, Kompetensi

\section{Abstract}

Increasing the professional competence of Madrasah teachers in the industrial era 4.0 is very important, so an empowerment is needed. This empowerment aims to improve the professional competence of madrasah teachers in Cimaung sub-district, West Java Province. The approach to implementing empowerment uses Asset Based Community Development (ABCD). This approach is used to optimize the potential and assets of the assisted community. The focus of this empowerment is training and assistance related to improving the professional competence of madrasah teachers in Cimaung sub-district. The results of empowerment show that the professional competence of madrasah teachers has increased significantly through several activities that have been carried out; literacy for early childhood, internalization of the values of Islamic education in curriculum and learning, as well as professional competence of teachers in the industrial era 4.0. Empowerment for madrasah teachers needs to be carried out continuously (continuous quality improvement) so that it can improve the competence of teachers properly. One of them is through training and empowerment conducted by $P T$.

Keywords: Teacher, Madrasah, ABCD, Industry, Competence

\section{Introduction}

Pendidik atau guru merupakan salah satu komponen yang sangat menentukan untuk terselenggaranya proses pendidikan. Keberadaan guru merupakan pelaku utama sebagai fasilitator penyelenggaraan proses belajar siswa (Prayitno, 2019; Rahmiyati, 2016). Oleh karena itu kehadiran dan profesionalisme seorang guru sangat berpengaruh dalam

$\begin{array}{lll}\text { History: } & & \text { Publisher: Undiksha Press } \\ \text { Received } & \text { : 02 August } 2020 & \text { Licensed: This work is licensed under } \\ \text { Revised } & : 09 \text { September } 2020 & \text { a Creative Commons Attribution 3.0 License } \\ \text { Accepted } & \text { : 06 October } 2020 & \text { : }\end{array}$


mewujudkan program pendidikan nasional (Alhamuddin \& Bukhori, 2016). Guru harus memiliki kualitas dan kompetensi yang memadai. Dalam hal ini seorang guru harus belajar, meningkatkan kompetensi dan wawasannya kompetensi guru terbagi menjadi 4, yaitu pedagogik, profesional, kepribadian, dan sosial (Kennedy, 2016; Leonard, 2016). Masingmasing kompetensi tersebut memiliki komponen-komponen yang harus dikuasai dengan baik oleh para guru, misalnya kompetensi pedagogik berbicara tentang kemampuan guru merencanakan, melaksanakan, dan akhirnya mengevaluasi pembelajaran (Leonard, 2016).

Hasil studi Heyneman \& Loxley, (1983) yang dilakukan di 29 Negara menunjukkan bahwa diantara berbagai masukan yang menentukan keberhasilan pendidikan (prestasi siswa) lebih dari sepertiganya ditentukan oleh guru. Menurut studi tersebut di 16 negara yang sedang berkembang (India, Mesir, Bosnia, Thailand, Chilie, El Savador, Kolombia, Meksiko, Brazil, Argentina, Peru, Uganda, Hongaria, Paraguay, Iran, dan Bolivia) guru memberikan kontribusi terhadap prestasi belajar sebanyak $34 \%$, manajemen $22 \%$, waktu belajar $18 \%$, dan sarana fisik $26 \%$. Sedangkan di 13 negara industri (Amerika Serikat, Inggris, Skotlandia, Belanda, Jerman, Swedia, Belgia, yang meliputi 3 kelompok etnis, Selandia Baru, Australia, Italia, dan Jepang) kontribusi guru $36 \%$, manajemen $23 \%$, waktu belajar $22 \%$, dan sarana fisik 19\% (Pramono, 2012; Sutardi \& Sugiharsono, 2016)

Sementara itu, menurut UU No. 20 Tahun 2003 Tentang Sistem Pendidikan Nasional pasal 39 ayat 3 dinyatakan sebagai berikut; "Pendidik merupakan tenaga profesional yang bertugas merencanakan dan melaksanakan proses pembelajaran, menilai hasil pembelajaran, melakukan bimbingan dan pelatihan, serta melakukan penelitian dan pengabdian kepada masyarakat, terutama bagi pendidik di Perguruan Tinggi". Kemudian Undang-Undang tersebut diperkuat oleh Undang-Undang No. 14 Tahun 2005 Tentang Guru dan Dosen, pada pasal 1 dinyatakan bahwa; "Guru adalah pendidik profesional dengan tugas utama mendidik, mengajar, membimbing, mengarahkan, melatih, menilai, dan mengevaluasi peserta didik pada pendidikan anak usia dini, jalur pendidikan formal, pendidikan dasar, dan pendidikan menengah". Guru memiliki peranan sebagai agen perubahan untuk itu kompetensi professional harus dimiliki oleh setiap guru (Tarbiyah \& Keguruan, 2017).

Tabel 1. Kompetensi Guru PAI Kota/Kab di Jawa Barat

\begin{tabular}{clcccc}
\hline \multirow{2}{*}{ No } & \multirow{2}{*}{ Kota/Kabupaten } & \multicolumn{4}{c}{ Kompetensi } \\
\cline { 3 - 6 } & Pedagogik & Kepribadian & Sosial & Profesional \\
\hline 1 & Ka. Bogor & 85.4 & 86.9 & 72.9 & 0 \\
2 & Kab Bandung Barat & 71 & 84.9 & 71.9 & 0 \\
3 & Kab Bandung & 89.5 & 75.6 & 91.5 & 0 \\
4 & Kab Garut & 87.6 & 86 & 94 & 25 \\
5 & kab Cirebon & 90 & 85.4 & 78.5 & 0 \\
6 & Kab Bekasi & 82.5 & 75.6 & 74.5 & 0 \\
7 & Kab Indramayu & 84.7 & 89.6 & 90.5 & 0 \\
8 & Kab Tasikmalaya & 84 & 82.3 & 86 & 25 \\
9 & Kota Bandung & 88.5 & 82.5 & 87.5 & 0 \\
10 & Kab Sumedang & 77 & 84.5 & 75.5 & 0 \\
11 & Kab Karawang & 81 & 80.5 & 76.5 & 0 \\
12 & Kab Sukabumi & 84 & 92.5 & 94.8 & 0 \\
13 & Kab Cianjur & 82.5 & 89.5 & 82.6 & 0 \\
14 & Kab Ciamis & 80.5 & 85.5 & 78.5 & 0 \\
\hline & Rata-Rata & $\mathbf{8 3 . 3}$ & $\mathbf{8 4 . 2}$ & $\mathbf{8 3 . 3}$ & $\mathbf{3 . 8}$ \\
\hline & & & & & (Ulfiah, 2016)
\end{tabular}


Berdasarkan data tabel 1 tersebut, kompetensi rata-rata tertinggi berada pada kompetensi kepribadian sebesar $84,3 \%$, sementara yang paling rendah adalah kompetensi profesional sebesar $5.4 \%$, terutama berhubungan dengan bukti fisik publikasi karya tulis ilmiah dan pengembangan bahan ajar. Angka 5.4\% sangat rendah sekali. Adapun kompetensi pedagogik dan sosial menunjukkan angka yang baik masing-masing $83.4 \%$ dan $82.5 \%$. Angka terendah untuk kompetensi pedagogik berada di Kabupaten Bandung Barat (71\%), sementara yang terbesar di Kabupaten Cirebon (90\%). Kompetensi kepribadian terendah berada di Kabupaten Bekasi dan Kabupaten Bandung, masing-masing 75.6\%, dengan kategori cukup baik. Kompetensi sosial terbesar berada di Kabupaten Sukabumi sebesar 94.8\% dan terendah di Kabupaten Bandung Barat 71.9\%, walaupun masih dalam kategori cukup baik. Yang paling rendah muncul pada kompetensi profesional khususnya pada publikasi karya ilmiah dan pengembangan bahan ajar, rata-rata $5.4 \%$ untuk seluruh kabupaten/kota. Data yang muncul sekitar $25 \%$ berada di Kabupaten Garut, Kabupaten Tasikmalaya, dan Kabupaten Sukabumi.

Komunitas madrasah menarik untuk diberdayakan, karena madrasah merupakan sistem pendidikan tertua di Indonesia. Ia merupakan fenomena sosio-kultural yang unik dan eksistensinya telah teruji oleh sejarah dan berlangsung hingga kini. Selain itu, madrasah sebagai sebuah sistem pendidikan yang memiliki akar historis dalam tradisi dan budaya bangsa ini, madrasah telah berkiprah secara signifikan pada setiap zaman yang dilaluinya; baik sebagai lembaga pendidikan dan pengembangan ajaran-ajaran Islam, sebagai kubu pertahanan Islam, sebagai lembaga perjuangan dan dakwah, maupun sebagai lembaga pemberdayaan dan pengabdian masyarakat (Farikhah, 2015). Sumbangsih madrasah juga sangat besar sebagai lembaga yang menanamkan pendidikan karakter anak bangsa yang mencakup delapan belas macam karakter yaitu religius, jujur, toleran, disiplin, bekerja keras, kreatif, mandiri, demokratis, rasa ingin tahu, semangat nasional, cinta tanah air, rasa hormat berprestasi, ramah atau komunikatif, cinta damai, suka membaca, lingkungan kepedulian, kepedulian sosial, dan tanggung jawab. Inti nya rata-rata indeks kontribusi madrasah diniyah untuk pendidikan karakter ada di kategori tinggi (Ikhrom et al., 2019; Mastiyah, 2018).

Dalam hal ini, madrasah berarti telah banyak berbuat untuk mendidik santri, hal ini mengandung makna bahwa pesantren mempunyai kontribusi yang signifikan dalam membangun atau membentuk pribadi warga negara dan bangsa menjadi pribadi muslim yang tangguh, harmonis, mampu mengatur kehidupan pribadinya, mengatasi persoalanpersoalanya dan mencukupi berargam kebutuhanya. Karena pendidikan pesantren, memiliki berbagai macam dimensi, baik psikologis, filosofis, religius, ekonomis, dan politis, sebagaimana ragamnya dimensi-dimensi pendidikan pada umumnya. Namun yang sangat disayangkan keberadaanya kadang-kadang dipandang sebelah mata dan di anak tirikan, baik dalam pembinaan maupun pembiayaan.

Pemberdayaan ini bertujuan untuk meningkatkan kompetensi professional guru madrasah di kecamatan Cimaung Provinsi Jawa Barat. Pendekatan dalam melaksanakan pemberdayaan menggunakan Asset Based Community Development (ABCD). Pendekatan ini digunakan untuk mengoptimalkan potensi dan aset yang dimiliki masyarakat mitra (Fitriawan, 2020). ABCD adalah pendekatan pengembangan masyarakat yang didasarkan pada asset lokal yang terdapat di suatu wilayah, asset tersebut dikembangkan sehingga dapat memecahkan masalah-masalah yang terdapat di wilayah dimana proses pemberdayaan dilaksanakan (Fithriyana, 2020). Pendekatan dalam melaksanakan pemberdayaan menggunakan Asset Based Community Development (ABCD) akan mampu memberikan kesempatan kepada mitra untuk mengatasi masalah-masalah yang dihadapi sehinga berdampak terhadap pendidikan. 


\section{Materials and Methods}

Pemberdayaan ini menggunakan pendekatan ABCD (Anas \& Ferrara, 2004) Untuk meningkatkan profesionalisme guru madrasah, diperlukan strategi pemberdayaan (Kerka, 2003) dengan melakukan berbagai kegiatan sebagai berikut: Pertama, pendekatan, dalam hal ini melakukan komunikasi langsung dengan pihak komunitas dampingan menyangkut masalah-masalah yang dihadapi para guru dalam proses pembelajaran. Dalam pendekatan ini tim menyampaikan maksud dan tujuan pemberdayaan. Langkah selanjutnya, tim dan komunitas dampingan mengidentifikasi masalah yang dihadapi para guru dalam pembelajaran hingga akhirnya menemukan core problem dan main problem. Dari core problem ini akan muncul pemetaan problem mana yang mendesak yang harus ditindaklanjuti. Pendekatan yang digunakan dapat berbentuk Collective meeting dan analisis kebutuhan yang berhubungan dengan kegiatan belajar mengajar di kelas.. Kegiatan ini bertujuan untuk menumbuhkan kepercayaan atas kemampuan dan kelebihan yang dimiliki oleh para guru dalam rangka meningkatkan kualitas pembelajaran. Selanjutnya, dari kesadaran individu, kemudian menjadi kesadaran kolektif untuk secara bersama-sama merencanakan sebuah aksi yang bertujuan untuk meningkatkan kualitas pembelajaran sehingga menghasilkan lulusan yang memiliki keunggulan kompetitif dan komperatif yang memiliki bobot intelektual, spritual, serta profesionalisme yang memadai.

Untuk program penguatan dan pemantapan, diarahkan pada dioalog interaktif (interactive dialogue). Dalam dialog interaktif ini, tim peneliti menggunakan strategi rapid assesment dan membantu memfasilitasi komunitas dampingan dalam memahami dan menggali masalahnya sendiri dalam konteks permasalahan yang cukup kompleks, agar kesadaran kritis dari komunitas dampingan dapat ditumbuhkembangkan. Dialog interaktif ini dapat ditempuh dalam berbagai pendekatan yaitu pertemuan kolektif, focus group discussions, face to face (individual meeting), transek dan Mapping.

Setelah dilaksanakan dialog interaktif, maka akan diperolah gambaran umum tentang permasalahan (summary problem) yang akan dijadikan pijakan berpikir (basic thinking) dalam rencana kerja (social planning). Dalam social planning, simpulan permasalahan dan kasus-kasus dikaji dan didiskusikan dengan menggunakan metode trend and change, diagram venn, kalender musim dan time line, analisis peristiwa kritis, pohon masalah, dan self evaluation terhadap concept map yang dibuat.

Kedua, perencanaan program, yaitu menyusun rencana aksi dan menganalisis segala kebutuhan yang diperlukan secara bersama-sama. Proses penysusun aksi akan dimulai dengan pemetaan masalah yang selama ini dihadapi para asatidz dalam pembelajaran. Pemetaan masalah diharapkan mampu memberikan kesadaran kolektif akan adanya hal-hal yang perlu dibenahi untuk meraih cita-cita dan tujuan mulia yaitu terciptanya suasana dan kondisi pembelajaran yang efektif dan efisien.

Ketiga, pelaksanaan program (action plan), yaitu mulai melaksanakan programprogram yang sudah drancang dalam tahapan perencanaan. Dalam pelaksanaan program, hal pertama yang dipikirkan adalah menyangkut pembiayaan, dengan demikian tim akan berupaya mencari terobosan dengan pihak luar untuk mendapatkan dana yang dibutuhkan oleh komunitas dampingan.

Keempat, refleksi dan evaluasi program. Refleksi dan evaluasi ini dilakukan setiap kali aksi selesai atau sedang dilakukan untuk melihat seberapa jauh tingkat keberhasilan dari harapan yang diinginkan. Selain itu, evaluasi program juga dilakukan untuk mengetahui seberapa jauh hasil yang telah dicapai dalam pelaksanaan program dengan tujuan mendapatkan umpan balik sebagai bahan untuk dijadikan renungan, catatan dan pemikiran dalam rangka penyusunan program pemantapan dan sosialisasi kepada pihak-pihak terkait. Pemberdayaan Komunitas guru Madrasah Ibtidaiiyah swasta pangalengan dilakukan berdasarkan pendekatan $A B C D$ `dengan langkah-langkah dapat dilihat pada grafik gambar 1. 


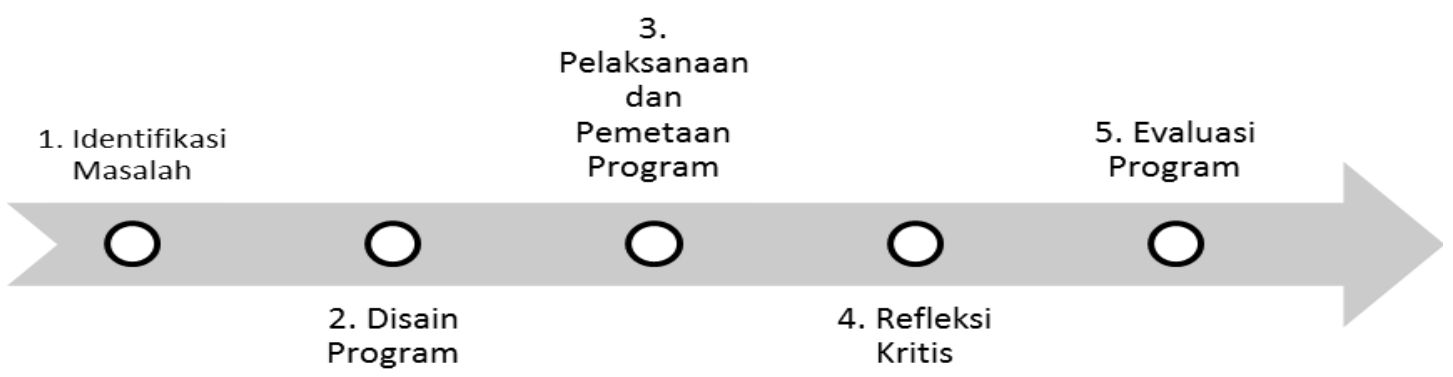

Gambar 1. Grafik Langkah-Langkah Metode Pelaksanaan PKM

\section{Results and Discussion}

Usaha perbaikan kualitas kehidupan manusia dengan pola pembangunan yang menempatkan manusia menjadi pelaku utama sudah dilakukan di Indonesia. Mengingat pola ini masih menjadi rintisan maka dukungan berbagai pihak sangat dibutuhkan. Perguruan tinggi sebagai salah satu lembaga pendidikan memiliki peran yang sangat strategis untuk ikut serta upaya ini. Sebuah usaha yang memastikan bahwa kegiatan pembangunan selayaknya menempatkan posisi manusia dapat berkembang kapasitasnya sesuai dengan segala potensi dan aset yang dimiliki. Lebih dari itu, perguruan tinggi dapat berperan dalam mewujudkan bagaimana terbentuknya manusia Indonesia yang memiliki kepedulian dan keaktifan sebagai warga negara.

Fokus kegiatan PKM untuk guru-guru Madrasah Ibtidaiyyah yang ada di kecamatan Pangalengan. Madrasah menarik untuk diberdayakan, karena madrasah memiliki kontribusi yang besar untuk pembangunan dan kemerdekaan bangsa ini. Madrasah merupakan hasil interaksi antara sekolah yang berbasis pengajaran agama dengan sekolah Hindia Belanda yang menekankan kepada peningkatan kecerdasan dan keterampilan kerja, sehingga Madrasah berdiri atas inisiatif dan realisasi dari pembaruan sistempendidikan Islam yang telah ada. Pembaruan tersebut, meliputi tiga hal, yaitu: usaha penyempurnaan terhadap sistem pendidikan pesantren, penyesuaian dengan sistem pendidikan Barat, dan upaya menjembatani antara sistem pendidikan tradisional pesantren dan sistem pendidikan Barat (Huda, 2016). Namun, keberadaan madrasah kadangkala dipandang sebagai kelas dua di masyarakat. Focus utama orang tua, lebih memilih sekolah umum terlebih dahulu, baru ketika anaknya tidak diterima di sekolah tersebut, madrasah sebagai alternative untuk melanjutkan studi. Selain sebagai kelas dua dalam paradigma masyarakat, secara kebijakan juga madrasah mendapatkan kelas dua secara perhatian dari pemerintah, mulai dana, beasiswa, dan bantuanbantuan lainnya yang dikelola pemerintah. Inilah salah satu kondisi madrasah di tengah masyarakat. Hal ini selaras dengan pendapat (Huda, 2016), bahwa dua problem ekternal yang menjadikan hambatan untuk madrasah dalam mengembangkan eksistensinya yaitu :problem politik dan pasrtisispasi masyarakat. Walaupun ada madrasah yang unggul, namun jumlahnya tidak sebanding dengan jumlah total madrasah yang ada di masyarakat.

Selain kondisi di atas, guru-guru madrasah secara kompetensi kadangkala masih rendah. Salah satu faktor rekrutmen untuk guru madrasah tidak dilakukan secara professional. Guru madrasah kebanyakan mengajar secara sukarela dan pengabdian. Inilah ruh yang dimiliki oleh madrasah dan pendidikan Islam pada umumnya. Empat faktor internal yang menjadi problema madrasah yaitu : pertama, kondisi guru yang belum memadai dan masih banyak guru yang mismach serta under qualified (Huda, 2016). Namun demikian pada prinsipnya guru madrasah memiliki hak sama untuk dikembangkan dan profesionalisme guru madrasah dapat dikembangkan (Tambak, 2020) 
Berangkat dari permasalahan tersebut, tim PKM LPPM Unisba melakukan mapping masalah yang dihadapi oleh guru-guru madrasah di lapangan, dari sekian banyak permasalahan yang dipaparkan, selanjutnya dibuat peta prioritas masalah yang akan dipecahkan terlebih dahulu, yaitu kompetensi guru di era revolusi industry 4.0. Dalam kegiatan PKM ini, tim menggunakan pendekatan Asset based Community development (ABCD). ABCD merupakan model pendekatan dalam pengembangan masyarakat (Blickem et al., 2018). Pendekatan ini menekankan pada inventarisasi aset yang terdapat di dalam masyarakat yang dipandang mendukung pada kegiatan pemberdayaan masyarakat.6 Pendekatan ABCD menggunakan 7 tahap kegiatan serial (Green, 2010). Penekanan pada asset reinventing menjadi ciri khas pendekatan ini, karena di dalam asset reinventing tersebut, diharuskan mengeksplorasi ketersediaan social assets yang dimiliki masyarakat. 7 Pendekatan ABCD digunakan sebagai usaha perbaikan kualitas kehidupan manusia dengan pola pembangunan yang menempatkan manusia menjadi pelaku utama (Blickem et al., 2018) sudah dilakukan di Indonesia. Mengingat pola ini masih menjadi rintisan maka dukungan berbagai pihak sangat dibutuhkan, terlebih lagi Perguruan tinggi sebagai salah satu lembaga pendidikan memiliki peran yang sangat strategis untuk ikut serta upaya ini.

Pendekatan ABCD digunakan Tim PKM dalam memberdayakan aset dan potensi guru-guru madrasah ibtidaiyyah untuk mendukung implementasi pembelajaran yang menarik dan menyenangkan. Hal ini selaras dengan penelitian (Taja et al., 2019), bahwa dengan banyaknya mata pelajaranyang menekankan pada hafalan dan harus diikuti oleh peserta didik maka guru madrasah dituntut untuk kreatif dan inovatif dalam mengemas teknik pembelajaran yang menyengkan meliputi kegiatan menyimak, bermain dan bercerita. Guru madrasah juga selayaknya memiliki kempuan dalam mengelola kelas juga kreatif dalam menyuguhkan materi (Arif \& Sulistianah, 2019). Oleh karena itu maka upaya yang dilakukan dalam pengabdian ini dimulai dari penyadaran dampingan akan pentingnya programvuntuk diikuti. Selanjutnya merencanakan dan melaksanakan bersama pengabdian bersama dengan mengedepan aset dan potensi yang dimiliki oleh dampingan, yaitu guru-guru madrasah yang ada di kecamatan Cimaung Kabupaten Bandung. .

Tim bersama dengan dampingan menyusun kegiatan untuk mendukung pencapaian tujuan tersebut, salah satunya dengan pelatihan terkait pembelajaran karakter, literasi di sekolah dasar, internalisasi nilai-nilai Islam dalam pembelajaran dan kurikulum madrasah, dan tema yang terakhir terkait kompetensi yang harus dimiliki guru pada era revolusi industry 4.0 (Alhamuddin et al., 2020). Salaha satu materi pelatihan yang disamapikan adalah pembelajaran literasi di sekolah dasar. Hal ini dikarenakan literasi di sekolah dasar memiliki peranan yang sangat penting terkait dengan membangun pembelajaran yang bermakna bagi anak. melalui kegiatan yang digulirkan pemerintrah yaitu Gerakan Literasi Sekolah (GLS), maka guru dituntut untuk mampu mengelola kegiatan membaca khususnya membaca atas inisiatif siswa sendiri dengan mendesain kegiatan agar hasil membaca anak dapat melahirkan sebuah karya atau produk yang dapat menumbuhkna jiwa tanggungjawab pada anak (Inten \& Puspita, 2020).

Langkah-langkah pemberdayaan berbasis asset dan resources dalam pendampingan sebagai berikut: Pada tahap perencanaan diuraikan sebagai berikut: Pertama, Tim PKM mempersiapkan progam dengan berdiskusi mengenai alternatif kluster, bentuk dan strategi yang akan digunakan serta asset dan pihak yang terlibat dalam kegiatan pemberdayaan. Hal ini dilakukan dengan cara mengisi matriks dan pohon masalah yang dihadapi oleh dampingan. Kedua, perencanaan Bersama mitra dapat berjalan dan berhasil dari kendala karena presentasi dan diskusi tentang draft program kerja disampaikan baik secara lisan maupun tertulis kepada mitra sasaran. Ketiga, penyusunan kepanitiaan dilakukan secara kolaboratif antara mitra pengabdian dan pihak pengabdi, baik sebagai panitia pelaksana keiatan maupun peserta kegiatan hingga penyedia sarana dan prasarana kegiatan. Keempat, 
pengesahan program dan penetapan kapan waktu acara akan dilaksanakan sesuai dengan kesepakatan bersama antara kedua belah pihak terkait.

Pada tahap pelaksanaan, pertama, rencana awal kegiatan dilaksanakan secara offline di madrasah toyyibah, ternyata sebelum pelaksanaan dunia dan termasuk Indonesia dilanda wabah Corona (Covid-19). Sehingga pelaksanaan diubah menjadi online dengan menggunakan fasilitas zoom meeting. Dengan adanya wabah Corona yang melanda dunia maka pembelajaran di sekolah dilaksankan dengan sistem dalam jaringan, pada hal ini guru dituntut untuk dapat mendesain pembelajaran yang dapat dilakukan oleh anak di rumah tanpa mengurangi kebermaknaan pembelajaran tersebut, namun hasil dari penelitian (Agustin et al., 2021), menyatakan bahwa $67,1 \%$ guru memiliki kendala dengan penggunaan teknologi yang harus digunakan dalam pembelajaran. Maka dalam PKM ini disampaikan pula bagaimana cara guru mendesain pembelajaran secara daring agar guru dapat mengkomunikasikan pada orang tua pembelajaran yang harus dilakukan dan anak dapat tetap belajar dengan baik walupun di rumah. Selanjutnya pada tahap evaluasi memakai mekanisme uji coba yang dilakukan oleh tim pengabdi melalui test kepada masyarakat dampingan untuk mengetahui peningkatan kemampuan mitra terkait kegiatan dampingan yang dilakukan.
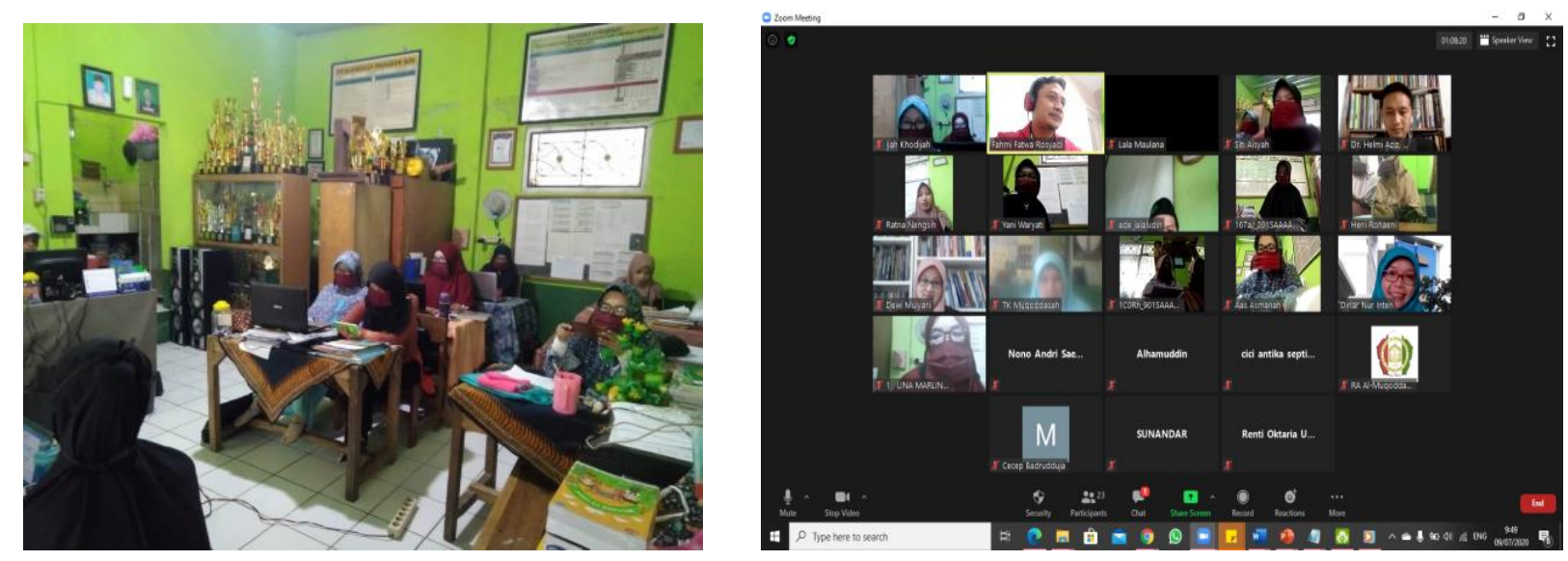

Gambar 2. Kegiatan Pemberdayaan

Berdasarkan paparan di atas, maka keberhasilan dalam pemberdayaan ini didukung oleh beberapa hal, di antaranya: pertama, Tim PKM dan mahasiswa sebelum tahap perencanaan telah melakukan pemetaan social. Pemetaan social dilakukan dengan cara mengunjungi lokasi sasaran dengan fokus utama pada lembaga pendidikan Islam yaitu madrasah. Hasil dari pemetaan social ini tim PKM mendapatkan peta konsep kegiatan pemberdayaan yang akan dilakukan untuk masyarakat dampingan. Kedua, kegiatan PKM yang menjadi acuan pelaksanaan program PKM pada saat perkenalan dengan stakeholder telah disertai dengan penjelasan maksud dan tujuan program secara jelas tentang kegiatan yang akan dilakukan, sehingga masyarakat dampingan memahami hal tersebut dengan baik. Ketiga, Tim PKM dalam pemetaan sosial tidak berhenti dengan dialog dan observasi, akan tetapi juga melakukan telaah dokumentasi untuk memperoleh data atau informasi yang valid mengenai kondisi masyarakat dampingan saat ini. Keempat, penentuan focus program PKM sangat memperhatikan hasil pemetaan sosial yang dilakukan oleh tim pengabdi. Dalam menentukan focus program tim pun mewawancara dan menganalisis kebutuhan para guru madrasah, diantara hasilnya adalah kebutuhan mereka akan metode serta strategi pembelajaran yang dapat digunakan oleh guru-guru di madrasah utamanya dalam mengajarkan pembelajaran agama, menurut (Ulpah, n.d.), guru-guru madrasah membutuhkan 
peningkatan kemampuan dalam strategi pembelajaran agar dapat menyampaian pembelajaran yang mudah dipahami oleh anak didik. Di saat wabah corona maka guru pun dituntut mampu menggunakan teknologi dengan baik karena bredasarkan hasil penelitian (Batubara et al., 2017), kompetensi TIK guru SD dan Mi masih perlu ditingkatkan khususnya untuk guru-guru yang berada di daerah terpencil. Model pemberdayaan yang bisa dilakukan beragam macam salah satu pelatihan. Tujuan pelatihan secara umum adalah mengubah perilaku individu tenaga pendidik di bidang pendidikan. Tujuan ini adalah menjadikan pendidikan sebagai suatu yang bernilai di masyarakat pendidikan, menolong individu agar mampu secara mandiri atau kelompok mengadakan kegiatan untuk mencapai kompetensi yang diharapkan (Sa'bani, 2017). Hasil pre-test dan post-test kegiatan dapat dilihat pada table di bawah ini.

Tabel 2. Paired Samples Statistics

\begin{tabular}{lccccc}
\hline \multicolumn{5}{c}{ Paired Samples Statistics } \\
\hline \multirow{2}{*}{ Pair 1 } & Mean & N & Std. Deviation & Std. Error Mean \\
& Pre & 64.67 & 30 & 17.760 & 3.242 \\
& Post & 84.00 & 30 & 16.733 & 3.055 \\
\hline
\end{tabular}

Tabel di atas menunjukkan bahwa rata-rata skor pre test peserta sebesar 64,47. Sedangkan rata-rata skor post test peserta sebesar 84. Artinya pemahaman peserta terhadap materi yang disampaikan mengalami peningkatan dengan selisih perbedaan rata-rata sebesar 29,33. Sedangkan hasil uji Paired Samples Test adalah sebagai berikut:

Tabel 3. Hasil Uji Paired Samples Test

\begin{tabular}{|c|c|c|c|c|c|c|c|c|c|}
\hline \multicolumn{10}{|c|}{ Paired Samples Test } \\
\hline & & \multicolumn{5}{|c|}{ Paired Differences } & \multirow{3}{*}{$\mathbf{t}$} & \multirow{3}{*}{ df } & \multirow{3}{*}{$\begin{array}{l}\text { Sig. } \\
(2- \\
\text { tailed })\end{array}$} \\
\hline & & \multirow[t]{2}{*}{ Mean } & \multirow{2}{*}{$\begin{array}{l}\text { Std. } \\
\text { Deviati } \\
\text { on }\end{array}$} & \multirow{2}{*}{$\begin{array}{l}\text { Std. } \\
\text { Error } \\
\text { Mean }\end{array}$} & \multicolumn{2}{|c|}{$\begin{array}{c}95 \% \text { Confidence } \\
\text { Interval of the } \\
\text { Difference }\end{array}$} & & & \\
\hline & & & & & $\begin{array}{c}\text { Lowe } \\
\mathbf{r}\end{array}$ & Upper & & & \\
\hline Pair 1 & $\begin{array}{c}\text { Post } \\
- \\
\text { Pre } \\
\text { Test }\end{array}$ & 19.333 & 24.486 & 4.470 & $\begin{array}{c}10.19 \\
0\end{array}$ & 28.476 & 4.325 & 29 & .000 \\
\hline
\end{tabular}

Hasil perhitungan uji Paired Samples Test memperoleh nilai signifikan sebesar 0,000 $<0,05$, sehingga dapat disimpulkan bahwa $\mathrm{Ha}_{0}$ ditolak dan $\mathrm{Ha}_{1}$ diterima, artinya terdapat perbedaan kompeteensi profesional peserta sebelum dan sesudah diberikan pemahaman materi. Sehingga dapat disimpulkan pemberdayaan guru-guru madrasah melalui pendekatan ABCD memiliki efektivitas dalam meningkatkan kompetensi profesional guru madrasah di era industri 4.0. peneltian sejalan dengan hasil penelitian yang dilakukan (Dooly, 2009) yang menyatakan bahwa pelatihan memiliki pengaruh terhadap peningkatan kompetensi guru. Hal serupa diungkapkan oleh (Purwoko et al., 2017)

Berdasarkan capain tersebut, (Saifudin \& In, 2020) pemberdayaan komunitas dalam menjalankan program untuk kepentingan mereka sendiri hanya dapat tercapai apabila melibatkan masyarakat. John McKnight dan Jody Kretzmann menggambarkan membangun komunitas dari dalam keluar sebagai jalan untuk menemukan dan mendaftar aset komunitas dalam beberapa kategori tertentu (misalnya aset pribadi, aset asosiasi atau institusi), warga 
komunitas belajar melihat kenyataan mereka sebagai gelas yang setengah penuh (Saifudin \& In, 2020). Sebelumnya, mereka melihat kebutuhan dan masalah, sekarang mereka lebih banyak melihat sumber daya dan kesempatan. Komunitas yang berhasil dibangun dalam PKM ini merupakan komunitas yang menyadari pentingnya dukungan aset dan potensi untuk mengatasi masalah yang sedang mereka hadapi sendiri (Saifudin \& In, 2020) (Practice et al., 2014).

\section{Conclusion}

Berdasarkan paparan dan diskusi di atas, maka pemberdayaan masyarakat perlu digunakan pendekatan yang memperhatikan potensi masyarakat dampingan. Dengan demikian, potensi yang ada dapat dikembangkan dengan baik dan akan mendukung keberhasilan dari program pemberdayaan tersebut. Pelibatan dampingan secara totally dalam kegiatan pemberdayaan juga menjadi faktor penentu untuk keberhasilan pemberdayaan masyarakat.

\section{References}

Agustin, M., Puspita, R. D., Nurinten, D., \& Nafiqoh, H. (2021). Jurnal Obsesi : Jurnal Pendidikan Anak Usia Dini Tipikal Kendala Guru PAUD dalam Mengajar pada Masa Pandemi Covid 19 dan Implikasinya Abstrak. 5(1), 334-345. https://doi.org/10.31004/obsesi.v5i1.598

Alhamuddin, A., Tsaury, A. M., \& Murniati, A. (2020). Competence of Islamic Higher Education Graduates from the Perspectives of Stakeholders in the Era of Industrial

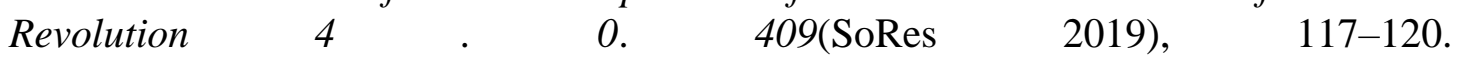
https://doi.org/doi.org/10.2991/assehr.k.200225.025

Alhamuddin, \& Bukhori. (2016). The Effect of Multiple Intelligence-Based Instruction on Critical Thinking of Full Day Islamic Elementary Schools Students. 21(1), 31-40. http://jurnal.radenfatah.ac.id/index.php/tadib/article/download/590/pdf/

Anas, J., \& Ferrara, L. (2004). Detecting Cyclical Turning Points: The ABCD Approach and Two Probabilistic Indicators. Journal of Business Cycle Measurement and Analysis, 2004(2), 193-225. https://doi.org/10.1787/jbcma-v2004-art12-en

Arif, M., \& Sulistianah, S. (2019). Problems in 2013 Curriculum Implementation for Classroom Teachers in Madrasah Ibtidaiyah. Al Ibtida: Jurnal Pendidikan Guru MI, 6(1), 110. https://doi.org/10.24235/al.ibtida.snj.v6i1.3916

Batubara, D. S., Negeri, U. I., Ibrahim, M. M., Dasar, S., \& Ibtidaiyah, M. (2017). Kompetensi Teknologi Informasi dan Komunikasi Guru SD/MI (Potret, Faktor-faktor, dan Upaya Meningkatkannya) INFORMASI ARTIKEL. 3(1), 48-65.

Blickem, C., Dawson, S., Kirk, S., Vassilev, I., Mathieson, A., Harrison, R., Bower, P., \& Lamb, J. (2018). What is Asset-Based Community Development and How Might It Improve the Health of People With Long-Term Conditions? A Realist Synthesis. SAGE Open, 8(3), 15-21. https://doi.org/10.1177/2158244018787223

Dooly, M. (2009). New competencies in a new era? Examining the impact of a teacher training project. ReCALL, 21(3), 352-369. https://doi.org/10.1017/S0958344009990085

Farikhah, S. (2015). Manajemen Lembaga pendidikan. Aswaja Persindo.

Fithriyana, E. (2020). Pengolahan Produk Berbahan Dasar Buah Pepaya Sebagai Upaya Pemberdayaan Ekonomi Masyarakat Pedesaaan. Jurnal Pengabdian Kepada 
Masyarakat, $\quad$ 1(2), $\quad 1-9 . \quad$ http://ejournal.sunan-giri.ac.id/index.php/ALUMRON/article/view/301

Fitriawan, F. (2020). Pemberdayaan Ekonomi Pemuda Melalui Budidaya Jamur Tiram. Amalee: Indonesian Journal of Community Research \& Engagement, 1(01), 47-58. amalee:

Indonesianhttp://download.garuda.ristekdikti.go.id/article.php?article=1284087\&val= 17192\&title

Green, G. P. (2010). Mobilizing Comunities Asset Building as a Community Development Strattegy. Temple University.

Heyneman, S. P., \& Loxley, W. A. (1983). The effect of primary-school quality on academic achievement across twenty-nine high- and low-income countries. American Journal of Sociology, 88(6), 1162-1194. https://doi.org/10.1086/227799

Huda, K. (2016). Problematika Madrasah Dalam Meningkatkan Mutu Pendidikan Islam. Jurnal Dinamika Penelitian, 16(2), 310-336. https://doi.org/10.21274/dinamika.2016.16.2.309-336

Ikhrom, I., Junaedi, M., \& Ismail, A. (2019). Contribution Index Of Madrasah Diniyah To The Character Education. In Analisa: Journal of Social Science .... researchgate.net.

Inten, D. nur, \& Puspita, R. D. (2020). International Webinar Series- Educational Revolution in Post Covid Era.

Kennedy, M. M. (2016). How Does Professional Development Improve Teaching? Review of Educational Research, 86(4), 945-980. https://doi.org/10.3102/0034654315626800

Kerka, S. (2003). Community asset mapping. Clearinghouse on Adult, Career, and Vocational Education: Trends and Issues Alert, 47, 1-2.

Leonard, L. (2016). Kompetensi Tenaga Pendidik di Indonesia: Analisis Dampak Rendahnya Kualitas SDM Guru dan Solusi Perbaikannya. Formatif: Jurnal Ilmiah Pendidikan MIPA, 5(3), 192-201. https://doi.org/10.30998/formatif.v5i3.643

Mastiyah. (2018). Vol. 41, No. 1, Juni 2018.41(1). https://doi.org/10.47655/dialog.v41i1.280

Practice, C., Identifier, D. O., Document, E., \& General, C. P. (2014). Edinburgh Research Explorer Neoliberalism with a community face? 22(4), 430-450.

Pramono, H. (2012). Pengaruh Sistem Pembinaan, Sarana Prasarana Dan Pendidikan Latihan Terhadap Kompetensi Kinerja Guru Pendidikan Jasmani Sekolah Dasar Di Kota Semarang. Jurnal Penelitian Pendidikan Unnes, 29(1), 124838. https://doi.org/10.15294/jpp.v29i1.5640

Prayitno, P. J. (2019). Pelaksanaan Supervisi Akademik Untuk Meningkatkan Kompetensi Pedagogik Guru Sma. Jurnal Visi Ilmu Pendidikan, 11(2), 46. https://doi.org/10.26418/jvip.v11i2.33209

Purwoko, A. A., Andayani, Y., \& Diartha, I. N. (2017). Jurnal Pendidikan IPA Indonesia Efforts In Improving Teachers' Competencies Through Collaboration Between Teacher Forum On Subject Matter ( Mgmp ) And Pre-Service Teacher Training. 6(1), 11-15. https://doi.org/10.15294/jpii.v6i1.8858

Rahmiyati, Y. (2016). Korelasi antara Kompetensi Kepribadian Guru dengan Minat dan Aktifitas Belajar Siswa di Madrasah Aliyah Samarinda. SYAMIL: Jurnal Pendidikan Agama Islam (Journal of Islamic Education), 4(2), 59-74. https://doi.org/10.21093/sy.v4i2.713 
Sa'bani. (2017). Peningkatan Kompetensi Guru dalam Menyusun RPP melalui Kegiatan Pelatihan pada MTs Muhammadiyah Wonosari. 2.

Saifudin, A., \& In, A. (2020). Pembinaan Teknik Berpidato dalam Meningkatkan Kreatifitas Santri. 2(2), 51-58.

Sutardi, S., \& Sugiharsono, S. (2016). Pengaruh Kompetensi Guru, Motivasi Belajar, Dan Lingkungan Keluarga Terhadap Hasil Belajar Mata Pelajaran Ekonomi. Harmoni Sosial: $\quad$ Jurnal Pendidikan IPS, 3(2), 188-198. https://doi.org/10.21831/hsjpi.v3i2.8400

Taja, N., Inten, D. N., \& Hakim, A. (2019). Upaya Meningkatkan Keterampilan Mengajar Baca Tulis Al-Qur`an bagi Guru. Jurnal Obsesi : Jurnal Pendidikan Anak Usia Dini, 3(1), 68. https://doi.org/10.31004/obsesi.v3i1.135

Tambak, S. (2020). Strengthening Islamic behavior and Islamic psychosocial in developing professional Madrasah teachers. Cakrawala Pendidikan, 39(1), 65-78. https://doi.org/10.21831/cp.v39i1.26001

Tarbiyah, A. F., \& Keguruan, D. (2017). Studi Perbandingan Kurikulum Pendidikan Dasar Negara Federasi Rusia dan Indonesia. 3(2), 2406-2775.

Ulfiah. (2016). Laporan Penelitian Kompetensi Guru Pendidikan Agama Islam Bersertifikasi pada SMA / SMK di Jawa Barat (Issue Mdc). Kementerian Agama dan MDC Jawa Barat.

Ulpah, M. (n.d.). Analisis Kompetensi Profesional Guru Madrasah Ibtidaiyah Di Purwokerto. 15(1), 152-162. 